\title{
The Effect of Mental Maps to Develop the Sensory Memory of the Skill of Starting Free Swimming and Achieving (50) Freestyle Meters
}

\author{
Moheb Hamid Raja \\ College of Physical Education and Sports Sciences, Tikrit University, Iraq.m.h.sport@tu.edu.iq
}

\begin{abstract}
This study aims to show the importance of the mental map for the skill of starting the learner in free swimming .It also Identifies the importance of the mental map to develop the sensory memory in starting from the platform in free swimming and achieving (50) meters. There are statistically significant differences for the research sample in favor of the experimental group. In this group, the mental map is used to develop the perceptual memory of the skill of starting free swimming .The researcher used the experimental approach in a controlled equal group method with two pre and post tests. This approach suits the nature of the problem. The research population was first grade students and the research sample was the students who know free swimming at Tikrit University for the academic year 2018-2019. The sample was divided into control and experimental groups, six students in each group. The students knew freestyle swimming and did not learn to start from the platform, and the researcher used the statistical method of SPSS for the purpose of data processing.
\end{abstract}

Keywords:

Mental maps - sensory memory - initiation into free swimming - achievement - research objective

Article Received: 18 October 2020, Revised: 3 November 2020, Accepted: 24 December 2020

\section{1- Introduction and study importance}

The learning stage is the task of scientific research workers which aims to help the learners achieve the highest level of learning as quickly as possible. This is what occupies the teacher and trainer to achieve the basic scientific goals in sports skills and the field of swimming. In particular, the researcher believes that the task of learning is not easy if there is a scientific and thoughtful planning according to the scientific rules of the skill to be studied.

The initial learning stage for each skill, and swimming in particular, is an important task that the teacher achieves for the purpose of consolidating the important information in the mind of the learner. The teacher also makes it a dynamic program in the learner's brain. This is because of the importance and achievements of the educational programs and with the fastest means with the least time and cost. This makes the teacher plan many programs and choose the most appropriate and easiest applicable to achieve its goal.

The researcher considers the importance of dealing with the human mind appropriately according to the mental capacity to develop a certain skill. Mental habits are how large information, but rather they are how to use this information in learning, which can be retrieved and recalled at the appropriate time. In Addition, the researcher believes that most of the teachers are trying to establish the educational position to recall the situation, place and time suitable for the purpose of the application. Here, the learner, refine, memorize, and apply the information in a scientific and thoughtful manner. Thus, the learner can link all parts of the educational skill in the form of a movement chain in the brain to become ready.

The importance of the research lies in identifying the importance of stimulating information and images for the previously learned skill through mental maps. These maps help the learner to develop mental habits and educational behaviors to make it easier for the learner to recall information about the educational situation to be applied at a later time.

\section{2- Study problem}


As a teacher in physical education and a teacher of swimming, the researcher noticed the lack of the use of mental maps that simulate the mind of the learner in learning the skills to start free swimming. Therefore, I decided to study this problem and develop appropriate solutions to achieve learning according to a well-thought-out plan to develop the sensory memory of the learner to face the educational situation required to be implemented.

The research problem lies in answering the following question:

Does the mental map help the learner in developing the sensory skill to start from the platform in free swimming and achieve (50) meters?

\section{3- Aims of study}

The study aims to show importance of the mental map for the skill of starting the learner in free swimming.

It also attempts to recognize the importance of the mental map for developing the sensory memory of the skill of starting from the platform in free swimming and achieving (50) meters.

\section{4- Study Hypothesis}

There are statistically significant differences in the research sample for the benefit of the experimental group. In this group, the mental map to develop the perceptual memory of the skill of starting free swimming is used.

\section{5- Scope of research}

The sample is consists of first-stage students, the College of Physical Education, and the freeswimming learners in The Saad Sports Club swimming pool from $3 / 3 / 2019$ to $5 / 30 / 2019$.

\section{3-1- Methodology}

The researcher used the experimental method show of the nature of the research using equal groups method.

\section{3-2Research population and sample:}

The research population were from students of the College of Physical Education and Sports
Sciences first grade. The research sample was chosen from (12) students of the first stage of Tikrit University for the academic year 2018-2019 who know free swimming and did not learn the skill of starting from the legal start platform. The sample was randomly distributed into two control and experimental groups. Each group contained (6) students who know free swimming and did not learn to start from the platform. The percentage of sample representation was (15\%) from the research community, noting that swimming is an individual sport.

\section{3-3Methods of gathering information}

3-3-1 Personal Interviews: The purpose of the interviews was to determine the physical characteristics and skill under study and the importance of starting freestyle swimming.

\section{3-3-2 Measurements and tests for the purpose of homogeneity:}

Height, mass, and age were calculated for the research sample, and Table (1) shows the homogeneity between the two research groups B (height, mass, age).

\begin{tabular}{|c|c|r|r|r|r|}
\hline $\begin{array}{c}\text { Measure } \\
\text { ment }\end{array}$ & $\begin{array}{r}\text { Un } \\
\text { it }\end{array}$ & $\begin{array}{r}\text { Arithm } \\
\text { etic } \\
\text { mean }\end{array}$ & $\begin{array}{r}\text { Mo } \\
\text { de }\end{array}$ & $\begin{array}{r}\text { Stand } \\
\text { ard } \\
\text { deviat } \\
\text { ion }\end{array}$ & $\begin{array}{r}\text { Skew } \\
\text { ness }\end{array}$ \\
\hline Length & $\begin{array}{r}\text { C } \\
\text { m }\end{array}$ & 169,12 & 169 & 4,9 & 0,024 \\
\hline Mass & Kg & 68,43 & 68 & 3,39 & 0,12 \\
\hline Age & $\begin{array}{c}\text { ye } \\
\text { ar }\end{array}$ & 21,28 & 21 & 0,65 & 0,43 \\
\hline
\end{tabular}

The table shows that the values of the skewness coefficient for the variables (length, mass, age) of the research sample are $(0,024,0,430,12)$ and they are limited to \pm 1 and this affects the homogeneity of the sample.

\section{3-3-3 Measuring some physical exercises that affect starting free swimming:}

For the purpose of parity of the research sample, the researcher conducted physical examinations to equalize the two groups in the physical level. Three physical exercises appropriate to the sample 
and their physical level were determined. Table (2) shows that (Hassanein, 2004).

\section{1-3-3-3Abdominal muscle strength extension:} It was measured by the sitting test from lying down (from a bent knees position) (Kamal,2016).

2-3-3-3The characteristic strength of the muscles of the arms velocity: It was measured by the test of bending and extending the arms from a forward support position in (10 seconds) (Kamal, 2016).

3-3-3-3The explosive strength of the leg muscles: It was measured by the long jump stability test (Kamal, 2016).

Table (2) shows the arithmetic mean and standard deviation of the physical tests under study.

Table (2)

the arithmetic mean and the standard deviation (lying down, front standing, throwing a medical ball)

\begin{tabular}{|c|c|c|c|c|c|c|c|}
\hline \multirow[t]{2}{*}{ Variables } & \multicolumn{2}{|c|}{ Group (1) } & \multicolumn{2}{|c|}{ Group (2) } & \multirow{2}{*}{$\begin{array}{c}\text { Calculat } \\
\text { ed t } \\
\text { value }\end{array}$} & \multirow[t]{2}{*}{ Sig } & \multirow{2}{*}{$\begin{array}{c}\text { Level of } \\
\text { significance }\end{array}$} \\
\hline & $-\mathrm{C}$ & $\pm \mathbf{A}$ & $-\mathrm{C}$ & $\pm \mathbf{A}$ & & & \\
\hline $\begin{array}{l}\text { Power of endurance } \\
\text { (abdomen) }\end{array}$ & 8,050 & $\mathbf{0 , 5 1 5}$ & 8,187 & 0,339 & 0,630 & 0,701 & $\begin{array}{c}\text { Not } \\
\text { significant }\end{array}$ \\
\hline $\begin{array}{l}\text { distinctive power (for } \\
\text { both arms) }\end{array}$ & 12,02 & 2,114 & 11,76 & 2,602 & 0,496 & 0,645 & $\begin{array}{c}\text { Not } \\
\text { significant }\end{array}$ \\
\hline Standing jump & 2,125 & $\mathbf{0 , 3 1 8}$ & 2,07 & 0,314 & 0,324 & 0,751 & $\begin{array}{c}\text { Not } \\
\text { significant }\end{array}$ \\
\hline
\end{tabular}

- $\quad$ Not significant if level of significance is bigger than the level of significance at $(0.05 \%)$

The table reveals the level of significance is greater than the level of significance $(0.05 \%)$. This indicates the parity of the sample in the physical characteristics and below a single initiation line.

\section{4-3Exploratory Experience:}

The researcher conducted the survey experiment on Thursday 28/2/2019 at exactly eleven o'clock in the swimming pool of Saad Sports Club to determine an initiation line to start the sample and the aim of the experiment was to:

1-show The efficiency of the assisting work team.

2- show how to implement the research steps.

3-Identify the obstacles that may encounter the researcher and research.

\section{5-3Main Experience:}

The main experiment was applied on Sunday $3 / 3 / 2019$ by two educational units to teach the starting skill, because it is considered one of the most important skills in swimming. This is because most of the trainers rely on its development as it gains time and distance. Also, (12) educational units distributed over (6) weeks (two educational units per week). The time of the educational unit was (60) minutes. The time is on Saturday and Wednesday, and the control group remained on the college curriculum according to the academic items, where the research sample was drawing a mental map of the exercises applied in the educational unit sequentially according to memory and the sensory and educational cases to be learned. Also, the learners work on applying exercises inside the water with the help of the teacher and the assistant work in teams.

\section{5-5-3Dimensional Tests:}

The post-tests were applied on Thursday 5/30/2019. The researcher prepared a performance evaluation form and presented it to experts on the subject of swimming. This is to evaluate the forms by those experts and give scores for each performance and according to the form's divisions: the apparent evaluation of movement 
and technical performance to start free swimming and achievement (50) meters.

\section{6-3statistical methods:}

The researcher used SPSS to process the data

\section{4- Results and discussion}

After completing the application of the main experiment of the research, the data were collected through the form of the virtual evaluation of the movement to identify the effect of making mental maps in appropriate educational situations. Table (3) shows the values of the mean and the deviation of the post-research sample.

Table (3), the values of the arithmetic mean, standard deviation, and value (t) for the post-test for the two groups in starting and completion (50) meters

\begin{tabular}{|c|c|c|c|c|c|c|c|}
\hline \multirow{3}{*}{ Fratistical paranceter } & \multicolumn{2}{|c|}{$\begin{array}{c}\text { Experimental } \\
\text { group }\end{array}$} & \multicolumn{2}{|c|}{ Control group } & \multirow[t]{2}{*}{$\begin{array}{l}\text { Claculated } \\
\text { t value }\end{array}$} & \multirow[t]{2}{*}{ Sig } & \multirow[t]{2}{*}{ Result } \\
\hline & $\mathbf{C}$ & $\mathbf{A \pm}$ & $\mathbf{C}$ & $\mathbf{A \pm}$ & & & \\
\hline & 9,166 & 0,278 & 4,416 & 0,374 & 0,917 & 0,000 & significant \\
\hline $\begin{array}{l}\text { Achievement (50)m } \\
\text { (sec) }\end{array}$ & 41,166 & 0,752 & 45,000 & 0,632 & 23,000 & 0,000 & significant \\
\hline
\end{tabular}

\section{- $\quad$ Level of the significance value is lower than the level of significance at $(0.05 \%)$}

Table (3) shows the values of the arithmetic mean for the start of free swimming and the achievement of the following $(9,166,4,416)$ and a standard deviation $(0,278.0,374)$ for the two groups. The mean values of the arithmetic reached $(41,166,45,000)$ for the achievement of (50) meters and with a deviation $(0,752,0,632)$ for the two groups. Also, in the control group, the value of the calculated (t) for the initiation and achievement test was $(0,917,23,000)$ for the two groups, which is higher than the tabular value and the significance level is less than $(0,05 \%)$. This indicates the existence of a significant difference in favor of the experimental group.

\subsection{Results and discussions}

It appears from table (3) that there are significant differences between the test for the two groups in learning to start free swimming and achieving (50) meters. This is confirms the hypothesis of the study. The confirmation could be because of the effect of mental maps drawn in the brain. It could also be attributed to the method of preserving and retrieving information and distributing the effort of the learner to free swim (50 meters) learning according to maps drawn by the brain throughout the program.

Al-Seliti (2008) arranged the material psychologically from easy to difficult and from simple to complex after the programmer. He also analyzed and placed it in a large number of small steps dependent on each other. Abd Al-Hussein, (2014) stated that the left hemisphere controls the analytical thinking, especially reading and writing and works on preparing information sequentially in the education system. This is what pushed educators to develop and activate the learning process and deal with things (logical, dealing with words, language, dealing with Information consecutively, and dealing with ideas, paying attention to minute details, and facing problems seriously). Abdul-Hussein (2015), and Faraj (2002) argued that the educational method 
contributes to the acquisition of motor skill quickly. They watched the kinetic model and the learners' practice of it helps in the motor skill to identify areas of weakness and strength in it. This in turn helps to exclude wrong movements and support the correct in them. Salem (2001) indicated when teaching any activity, the learners is placed in an educational position so that they have the mental and psychological readiness to acquire certain experiences that suit the abilities and aptitudes through the presence in this educational environment "(Salem, 2001, 29).

According to Mahjoob (2001), there are many benefits that can be noticed with the exercise, as it leads to the development of the skill and access to the correct technique. There are also some achievements of automation in performance and the ability to know and determine the error. Jaszczak (2011) emphasized the mutual interaction between its upper and lower limbs. Also, captioning the hand thrusting is characterized by a relatively constant level of asymmetric movement. This means the increase in the compensation of the local asymmetry caused incorrect leg movement. Also, this compensation appears most likely at the beginning of the hand movement. However, any asymmetry could occur at the end of the thrust of the upper limb (Jaszczak, 2011).

The researcher believes that the superiority of the experimental group over the control group that used the method of mental maps. He also proved the creation of the appropriate educational position that helps the learner to remember the skill sequentially and apply exercises and this explains the hypothesis of the research.

\section{Conclusions}

\section{1 findings}

5-1-1The researcher proved the effect of mental maps to teach the skill of starting and reducing time in free swimming.

5-1-2 The stimulation of the educational position in a timely manner makes it easier for the learner to recall information easily and in an uncomplicated manner.
15-1-3 The educational situation that the learner passes through whenever it is easy helps to store it in a part of the brain is easy to use in the appropriate educational outcome.

\section{5-2Recommendations:}

The study recommends the following:

5-2-1 Conducting similar research on a different sample of gender and age due to the importance of making mental maps.

5-2-2 Researchers could work to create the appropriate position for the skill to be studied with the educational position.

\section{References}

[1] Salem and Wafaqa M. (2001), Teaching and Learning Technology in Physical Education. Alexandria: Al Ma'arif Institute.

[2] Farag, E. W. (2002). Experiences in games for children and adults ( $2^{\text {nd }}$ ed). Alexandria: Ma'arif facility.

[3] Abdul-Hussein, W. (2014). Learning in harmony with the brain ( $1^{\text {st }}$ ed). Beirut: Dar Al-Kotob Al-Ilmiyya.

[4] Mahjoob, W. (2001). Learning and Training Scheduling ( $1^{\text {st }}$ ed). Amman: AlAwael Publishing House.

[5] Hassanein, M. S. (2004). Measurement and Evaluation in Physical Education and Sports, Part 1 (6 ${ }^{\text {th }}$ ed). Cairo: Dar AL-Fikr AL-Arabi.

[6] Al-Seliti, F. (2008). Learning Strategies and Teaching Theory and Practice ( $1^{\text {ST }}$ ed). Oman: a wall for the World Book.

[7] Ismael, K. A. (2016). Measurement and evaluation tests accompanying the science of human movement. Cairo: Al-Kitab Center for Publishing.

[8] Jaszczak, M. (2011). The influence of lower limb movement on upper limb movement symmetry while swimming the breaststroke. biology of sport, 28(3). 